\section{It's All About Trust!}

$I^{n}$ n February, national news media highlighted the struggle that some hospitals are facing in getting staff vaccinated for COVID-19. One hospital featured was Roseland Community Hospital in Chicago, a facility that serves local Black residents and has a high proportion of Black providers and staff. In this case, the problem was not access to vaccine, but vaccine hesitancy.

I was somewhat shocked by this. After all, Blacks have been hit so much harder than other Americans by this virus. And these care workers, like so many others across the country, have been battling in a fierce war that has taken many friends and family. Wouldn't the staff be eager to get some protection for themselves and, indirectly, their loved ones? I listened carefully to an interview with a care worker. She said she wasn't sure. The vaccine came along too fast. She was concerned about safety. This hesitancy was not about lack of education; it was about trust.

Black Americans have many reasons to be wary. The classic example of a root cause for this, of course, is the infamous Tuskegee Syphilis Study, which began in 1932 and ended in 1972. ${ }^{1}$ During this time, Public Health Service officials decided not to treat a cohort of Black men with syphilis so they could study the natural history of the disease. It seems barbaric today, but it was real. Clearly, to those public health officials, Black lives did NOT matter. It took until 1997 for the United States to issue a public apology, articulated by then-President Bill Clinton. But how can words alone erase such a heinous act?

In some weird way, the news about vaccine hesitancy among Black Americans also helped me understand why we have so much difficulty enrolling Black patients on clinical trials. If it is difficult for them to accept a proven remedy for a disease that is killing people in front of them, how much harder might it be to trust the potential benefit of an experimental cancer drug? Or to enroll in a trial where they might receive a placebo? A recent study of registration trials for new cancer drugs showed that only $1.9 \%$ of trial participants are Black, while US cancer statistics indicate that $10.8 \%$ of patients with cancer are Black. ${ }^{2}$ Something is wrong with this picture.

We in healthcare are embracing a number of strategies to change this. Obviously, there is an emphasis on bringing more healthcare workers of color onto every team. We have worked at the community level, especially in faith-based organizations, to encourage trust. And we have tried to emphasize diversity in messaging, including in educational materials.

But I think the basic lesion is a fundamental one. I don't think trust will be achieved until it is clear, in every sector of our society, by our words and by our actions, that Black lives DO matter.

\section{References}

1. Centers for Disease Control and Prevention. U.S. Public Health Service Syphilis Study at Tuskegee. The Tuskegee timeline. Accessed February 3, 2021. Available at: https://www.cdc.gov/tuskegee/ timeline.htm

2. Maniar R, Green A, Bach P, Mailankody S. Baseline demographics and disparities in cancer registration trials: an analysis of U.S. Food and Drug Administration approved drugs in 2015 and 2016 [abstract]. J Clin Oncol 2018;36(Suppl):Abstract e18623.

WHAT DO YOU THINK? To submit a Letter to the Editor, email JNCCN@nccn.org or log into www.editorialmanager.com/JNCCN.

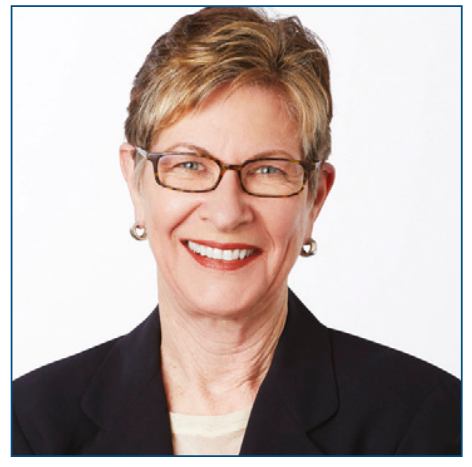

MARGARET TEMPERO, MD

Margaret Tempero, MD, is a Professor of Medicine and Director of the UCSF Pancreas Center and editor-in-chief of JNCCN. Her research career has focused on pancreatic ductal adenocarcinoma, especially in the area of investigational therapeutics. Dr. Tempero has served on the ASCO Board of Directors and as ASCO President. She currently serves on the ASCO Conquer Cancer Foundation Board. She codirected the AACR/ASCO Methods in Clinical Cancer Research and taught this course and similar courses in Europe and Australia. She was founding Chair of the $\mathrm{NCl}$ Clinical Oncology Study Section and served as a member and Chair of the $\mathrm{NCl}$ Board of Scientific Counselors Subcommittee A. She is a member of the Scientific Steering Committee and Chair of the Clinical and Translational Study Section for the Cancer Prevention \& Research Institute of Texas. She is or has been on the Scientific Advisory Boards of the Lustgarten Foundation, the Pancreatic Cancer Action Network, the V Foundation, The Alberta Canada Cancer Board, and the EORTC. She served as a member of the Oncology Drug Advisory Committee for the FDA. She has served as Deputy Director and Interim Director for the UNMC Eppley Cancer Center. She is Chief Emeritus of the Division of Medical Oncology at UCSF. She served as the founding Deputy Director and was later Director of Research Programs at the UCSF Helen Diller Family Comprehensive Cancer Center.

doi: 10.6004/jnccn.2021.0014

The ideas and viewpoints expressed in this editorial are those of the author and do not necessarily represent any policy, position, or program of NCCN. 